\title{
Experience of 80 cases with Fournier's gangrene and "trauma" as a trigger factor in the etiopathogenesis
}

\author{
Teoman Eskitaşcıoğlu, M.D., İrfan Özyazgan, M.D., Atilla Coruh, M.D., Galip K Günay, M.D., \\ Mehmet Altıparmak, M.D., Yalcin Yontar, M.D., Fatih Doğan, M.D. ${ }^{\dagger}$ \\ Department of Plastic Reconstructive and Aesthetic Surgery, Erciyes University Faculty of Medicine, Kayseri \\ ${ }^{+}$Current affiliation: Department of Plastic Reconstructive and Aesthetic Surgery, Adıyaman University Faculty of Medicine, Adıyaman
}

\begin{abstract}
BACKGROUND: The purpose of the present study was to retrospectively analyze the patients' data presented with Fournier's gangrene (FG), to compare obtained data with the literature and to investigate the role of "trauma" in the etiopathogenesis.

METHODS: A retrospective study was conducted on 126 patients with FG that consulted to our department.

RESULTS: There were 76 male and four female patients. The mean age of the patients was $53.5 \pm 13.6$ years. The most common presentation of patients was swelling $(n=74)$. The scrotum has been shown to be the most commonly affected area in the patients $(n=75)$. Diabetes mellitus was the leading predisposing factor and trauma was the leading responsible cause for FG. Escherichia coli was the most frequently identified microorganism $(n=43,53.75 \%)$. Primary closure was the most common technique used for all patients. Three patients exhibited a mortal course due to sepsis and multi-organ failure.
\end{abstract}

CONCLUSION: FG still has a high mortality rate. Rapid and correct diagnosis of the disease can avoid inappropriate or delayed treatment and even death of the patient. The healthcare professionals should be aware that any trauma in the perineal region could lead to FG.

Key words: Fournier's gangrene; reconstruction; trauma.

\section{INTRODUCTION}

Fournier's gangrene (FG) is an infectious necrotizing fasciitis of the perineal region that progressively spreads along the fascial planes. The necrotizing infection leads to obliterative endarteritis of dermal and subdermal perforating vessels resulting in gangrene of the subcutaneous tissue and the overlying skin. ${ }^{[1]}$ Colorectal region, genitourinary tract and cutaneous flora are the most common sources of the bacterial pathogens in FG. ${ }^{[2]}$ The infection is frequently polymicrobial and synergistic with several aerobic, or anaerobic microorganisms including Escherichia coli, Klebsiella, Staphylococcus, Streptococcus, Proteus, and Pseudomonas species. ${ }^{[3,4]}$

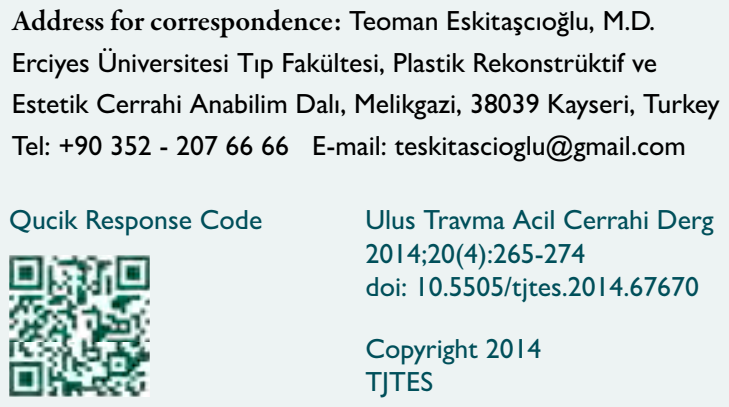

Risk factors for FG include increased age, ethanol abuse, immunosuppressive conditions such as diabetes mellitus (DM), steroid usage, malignancies, etc. ${ }^{[5-16]}$ Chronic renal failure, prehospital delay time, extent of the affected area, serum-blood urea nitrogen and creatinin level are some of the factors that affected the prognosis of the disease. ${ }^{[7]} \mathrm{FG}$ is associated with a mortality rate of $9-43 \% .{ }^{[17-24]}$

The purpose of the present study was to retrospectively analyze the patients' data presented with FG, to compare obtained data with the literature and to investigate the role of "trauma" in the etiopathogenesis of FG.

\section{MATERIALS AND METHODS}

A 17-year retrospective study was conducted on 126 patients with FG that consulted to the Department of Plastic and Reconstructive Surgery of Erciyes University Medical Faculty between January 1997 and May 2013. Of the patients, 80 with available hospital records were included in the study. The diagnosis of FG was made on the basis of clinical findings and anamnesis of the patients. Radiologic examinations were performed for the diagnosis of FG in suspected clinical presentations. Patients' data regarding age, sex, presenting features at hospital admission, anatomic distribution, pre-hospital delay 
time, predisposing factors, etiologic causes, treatment modalities, hospitalization time, and mortality rate were evaluated retrospectively. Pre-hospital delay was defined as the time from the onset of symptoms until hospital admission. Clustered data were analyzed statistically by using software package (SPSS for Windows, release 20.0.0; IBM, Chicago, IL, USA). This study was approved by the "Institutional Review Board of Erciyes University Medical Faculty."

\section{RESULTS}

\section{Age and Sex}

There were 76 male (95\%) and 4 female (5\%) patients with a male to female ratio of 19:1. The age of the patients ranged from 19 to 82 years, and the mean age was $53.5 \pm 13.6$ years. The highest incidence of FG was observed in the age group of $50-60$ years ( $n=25,31.25 \%$ ) (Fig. I) and the most affected patients were the males in this age group.

\section{Presenting Features at Hospital Admission}

The most common presentations of patients were swelling $(n=74,92.5 \%)$, pain $(n=42,52.5 \%)$, hyperemia $(n=21,26.25 \%)$, purulent discharge from the affected area $(n=18,22.5 \%)$, and fever $(n=16,20 \%)($ Table I).

Ultrasonography was the primary chosen diagnostic tool in 33 patients (4I.25\%) with suspected clinical presentations. Findings typically included marked thickening of the scrotal skin, subcutaneous gas, increased blood supply to the epididymis and testis, increased peritesticular fluid, abscess and hematoma formation.

\section{Anatomic Distribution}

The scrotum has been shown to be the most commonly affected area in the patients ( $n=75,93.75 \%)$. Other affected areas, in decreasing order of frequency were perianal region $(43.75 \%)$, penis $(22.5 \%)$, abdominal wall $(6.25 \%)$, gluteal region $(6.25 \%)$, pubis $(5 \%)$, inguinal region $(3.75 \%)$, vulva (3.75\%), sacral region (1.25\%), and thigh (1.25\%) (These numbers add to more than $100 \%$ because some patients had

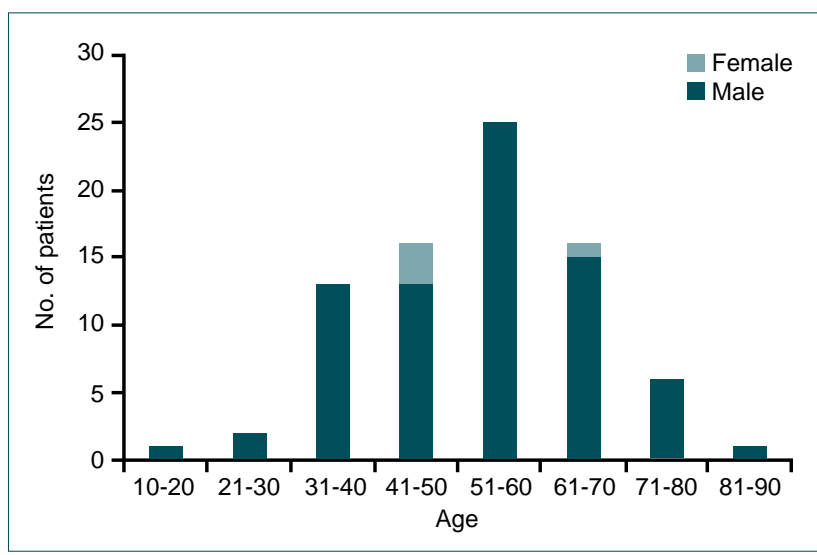

Figure 1. Distribution of patients according to age and sex.
Table I. Initial presentations of patients with Fournier's gangrene

\begin{tabular}{lcc}
\hline Finding & $\mathbf{n}$ & $\%$ \\
\hline Swelling & 74 & 92.5 \\
Pain & 42 & 52.5 \\
Hyperemia & 21 & 26.25 \\
Purulent discharge & 18 & 22.5 \\
Fever & 16 & 20 \\
Constipation & 4 & 5 \\
Urinary retention & 4 & 5 \\
Urinary incontinence & 3 & 3.75 \\
Fecal incontinence & 1 & 1.25 \\
\hline
\end{tabular}

more than one affected area). The incidence of the abdominal wall involvement was $75 \%$ in female $(3 / 4)$ and $2.6 \%$ in male patients $(2 / 76)$. Unilateral necrotic testis was observed in six patients $(7.5 \%)$.

\section{Pre-hospital Delay Time}

The mean pre-hospital delay time of the patients was $5.48 \pm 4.55$ days (range, I-25 days). The duration of symptoms before hospital admission was I day in I I patients (I3.75\%), 2-4 days in 31 patients (38.75\%), 5-7 days in 24 patients (30\%), and more than 7 days in 14 patients (17.5\%) (Fig. 2).

\section{Predisposing Factors}

Of the patients, 62 had one or more than one predisposing factor for FG. DM (42.5\%), smoking (27.5\%), and hypertension $(16.25 \%)$ were the leading ones that followed by benign prostatic hyperplasia (BPH), coronary artery disease (CAD), chronic obstructive pulmonary disease, paraplegia, hemiplegia, ethanol abuse, chronic renal insufficiency, pancytopenia, cachexia, Leriche syndrome, and familial Mediterranean fever, respectively (Table 2 ).

\section{Etiologic Causes}

Etiologic causes were identified in $4 \mathrm{I}$ patients (5I.25\%). Trauma $(n=20,25 \%)$, colorectal diseases $(n=16,20 \%)$, and genito-

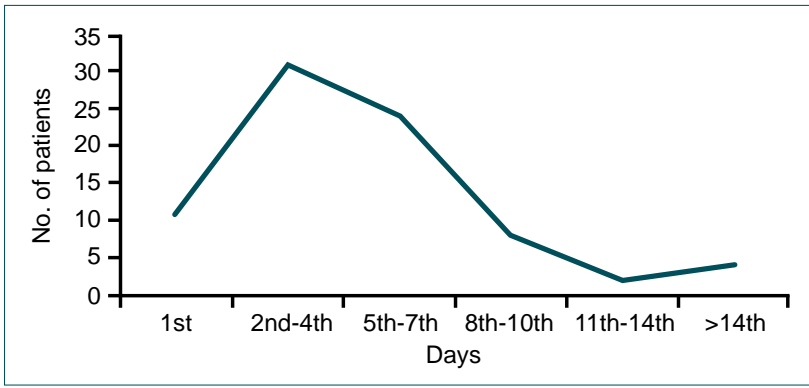

Figure 2. Distribution of patients according to time of hospital admission. 
Table 2. Predisposing factors of patients with Fournier's gangrene

\begin{tabular}{lcc}
\hline Predisposing factor & $\mathbf{n}$ & $\%$ \\
\hline Diabetes mellitus & 34 & 42.5 \\
Smoking & 22 & 27.5 \\
Hypertension & 13 & 13.75 \\
Benign prostatic hyperplasia & 8 & 10 \\
Coronary artery disease & 7 & 8.75 \\
Chronic obstructive pulmonary disease & 6 & 7.5 \\
Hemorrhoid & 5 & 6.25 \\
Paraplegia & 4 & 5 \\
Hemiplegia & 2 & 2.5 \\
Ethanol abuse & 2 & 2.5 \\
Chronic renal insufficiency & $\mathrm{I}$ & 1.25 \\
Pancytopenia & $\mathrm{I}$ & 1.25 \\
Cachexia & $\mathrm{I}$ & 1.25 \\
Leriche syndrome & $\mathrm{I}$ & 1.25 \\
Familial Mediterranean fever & $\mathrm{I}$ & 1.25 \\
\hline
\end{tabular}

urinary disorders $(n=5,6.25 \%)$ were the responsible causes for FG. Furthermore, there were no etiological factors in 39 patients (48.75\%). In total, perianal abscess was the leading etiologic factor for FG ( $n=9,11.25 \%)$.

Traumatic factors were divided into two main groups according to the mechanism of injury: (I) surgical and (2) nonsurgical trauma. Of the patients, 12 had undergone invasive therapeutic procedures within 2 months prior to disease onset including drainage of perianal abscess, hemorrhoidectomy, incisional hernia repair, femoral hernia repair, caesarean section, surgery for penetrating intestinal injury, flap closure of sacral pressure sore, balloon dilatation for $\mathrm{BPH}$, and transurethral resection of prostate (TUR-P).

One of our patients had burn injury of the lower extremities that resulted in unhealed burn wound and one with Leriche syndrome had a trauma that caused by falling on to the hip. Among the patients, farmers were the most common occupational group $(n=13,16.25 \%)$ in whom six of them had a history of chronic perineal irritation due to pricking of thorn (Table 3).

\section{Microbiology and Antibiotherapy}

Positive bacteriologic cultures were obtained in 74 (92.5\%) patients and the infection was polymicrobial in 14 patients (I7.5\%). E. coli was the most frequently identified microorganism ( $n=43,53.75 \%$ ) that followed by; Staphylococcus aureus, Enterococcus, Acinetobacter baumani, Staphylococcus epidermidis, Streptococcus spp., Proteus, Citobacter, Bacteriodes, Klebsiella oxycata, and Prevotella, respectively (Table 4).
Table 3. Identified etiologic factors for Fournier's gangrene

\begin{tabular}{|c|c|c|}
\hline Etiologic factor & $\mathbf{n}$ & $\%$ \\
\hline Colorectal diseases & 16 & 20 \\
\hline Perianal abscess & 9 & 11.25 \\
\hline Anal fissure & 3 & 3.75 \\
\hline Perianal fistula & 2 & 2.5 \\
\hline Colorectal carcinoma & 2 & 2.5 \\
\hline Genitourinary disorders & 5 & 6.25 \\
\hline Urethral stricture & 4 & 5 \\
\hline Bladder carcinoma & 1 & 1.25 \\
\hline Trauma & 20 & 25 \\
\hline Non-surgical trauma & 8 & 10 \\
\hline Chronic perineal irritation & 6 & 75 \\
\hline Falling down & 1 & 1.25 \\
\hline Burn injury of lower extremities & 1 & 1.25 \\
\hline Surgical trauma & 12 & 15 \\
\hline Drainage of perianal abscess & 3 & 3.75 \\
\hline Hemorrhoidectomy & 2 & 2.5 \\
\hline Hernia repair & 2 & 2.5 \\
\hline Flap closure of sacral pressure sore & 1 & 1.25 \\
\hline Surgery for penetrating intestinal injury & 1 & 1.25 \\
\hline Caesarean section & 1 & 1.25 \\
\hline Balloon dilatation for $\mathrm{BPH}$ & 1 & 1.25 \\
\hline Trans-urethral resection of prostate & 1 & 1.25 \\
\hline Total & 41 & 51.25 \\
\hline
\end{tabular}

BPH: Benign prostatic hyperplasia.

Table 4. Identified causative pathogens of patients with Fournier's gangrene

\begin{tabular}{lcc}
\hline Microorganism & $\mathbf{n}$ & $\%$ \\
\hline Escherichia coli & 43 & 53.75 \\
Staphylococcus aureus & 12 & 15 \\
Enterococcus & 9 & 11.25 \\
Acinetobacter baumani & 5 & 6.25 \\
Staphylococcus epidermidis & 5 & 6.25 \\
Other Streptococcus spp. & 4 & 5 \\
Proteus & 4 & 5 \\
Citobacter & $\mathrm{I}$ & 1.25 \\
Bacteroides & $\mathrm{I}$ & 1.25 \\
Klebsiella oxycata & $\mathrm{I}$ & 1.25 \\
Prevotella & $\mathrm{I}$ & 1.25 \\
\hline
\end{tabular}

All patients received empiric antibiotic regimen intravenously including the combination of a third-generation cephalospo- 
rin and metronidazole. The most preferred antibiotics according to antibiotic susceptibility results were ciprofloxacin $(n=40)$ and clindamycin $(n=34)$.

\section{Surgical Management}

All patients underwent aggressive surgical debridement of the necrotic tissues by the departments of general surgery or urology, averaging 1.55 \pm 1.15 operations/patient (range, I-8 debridements). Serial debridement of the necrotic tissues was required for 24 patients (30\%). Time to initial debridement from the disease onset was ranged from I to 29 days with a mean value of 6.05 days. Debridement was performed in the same day of hospital admission in 60 patients (75\%) (Fig. 3).

Orchiectomy was carried out unilaterally in six patients (7.5\%) due to presence of necrotic testis. Radical vulvectomy was performed in one of the female patients due to grossly necrotic external genitalia.

Colostomy was performed in 12 patients (I5\%) for fecal diversion who had a high risk of fecal contamination in the presence infected anal sphincter, or large perianal defects. Urinary diversion is provided by suprapubic cystostomy in seven patients $(8.75 \%)$ because of urethral involvement that resulted in urinary extravasation.

We could not apply any reconstructive technique in one of the consulted patients due to rapid mortal course. The distribution of the reconstructive techniques shows that performing primary closure alone $(n=27,33.75 \%)$ was the most common technique used for all patients. The others were listed in Table 6.

\section{Hospitalization Time}

The mean hospitalization time of the patients was $34.78 \pm 18.83$ days (range, $8-106$ days). It was $33.73 \pm 17.30$

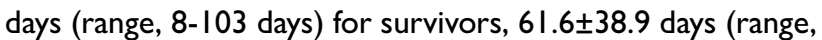
33-106 days) for non-survivors.

\section{Mortality}

Of the patients, three exhibited a mortal course due to sepsis

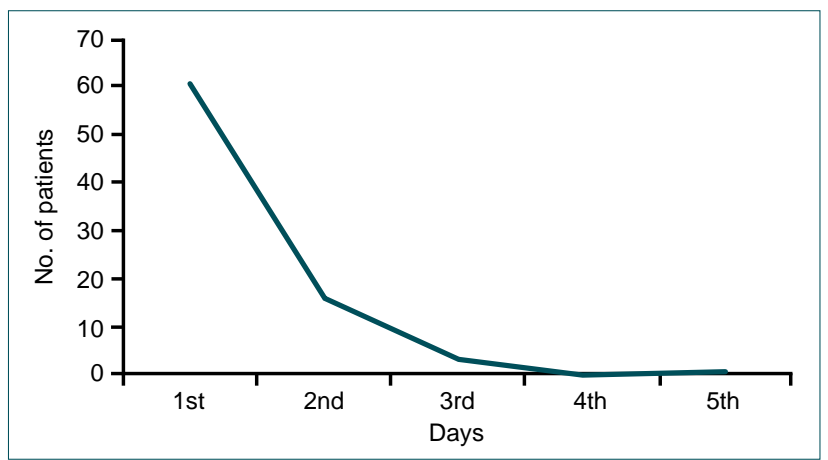

Figure 3. Time to initial debridement from the disease onset. and multi-organ failure. The mortality rate of patients with abdominal wall involvement was $40 \%(2 / 5)$ in whom one of them was male and one was female.

\section{DISCUSSION}

The scrotal gangrene was published for the first time by Baurienne in an article named "Sur une Plaie contuse qui

Table 5. Preferred antibiotic according to antibiotic susceptibility results

\begin{tabular}{ll}
\hline Antibiotic & $\mathbf{n}$ \\
\hline Ciprofloxacin & 40 \\
Clindamycin & 34 \\
Ornidazole & 10 \\
Cephaperazon-sulbactam & 8 \\
Amicasin & 5 \\
Imipenem & 5 \\
Metronidazole & 5 \\
Piperacillin-tazobactam & 5 \\
Ampicillin-sulbactam & 4 \\
Teicoplanin & 4 \\
Aztreonam & 2 \\
Cephtriaxon & 2 \\
Ertapenem & 2 \\
Ceftazidime & I \\
Cefixime & I \\
Gentamicin & I \\
Neutromycin & I \\
Polymyxin E & I \\
\hline &
\end{tabular}

Table 6. Applied reconstructive techniques for closure of the cutaneous defects

\begin{tabular}{lcc}
\hline Technique & n & $\%$ \\
\hline Primary closure & 27 & 33.75 \\
Scrotal flap & II & 13.75 \\
Primary closure + skin grafting & 10 & 12.5 \\
Skin grafting & 8 & 10 \\
Scrotal flap + skin grafting & 6 & 7.5 \\
Pudendal thigh fasciocutaneous flap & 5 & 6.75 \\
Scrotal flap + primary closure & 4 & 5 \\
Gracilis musculocutaneous flap & 2 & 2.5 \\
Medial thigh flap & 2 & 2.5 \\
Super-thin groin island flap & 2 & 2.5 \\
Abdominal advancement flap + skin grafting & 2 & 2.5 \\
Total & 79 & 100 \\
\hline
\end{tabular}


s'estterminée par le sphacele de tout le scrotum" (I764). ${ }^{[25]}$ Jean Alfred Fournier, the French venereologist after whom the term "FG" was named, reported five cases that presented with fulminant gangrene of the scrotum and penis (1883-84). ${ }^{[26,27]}$

Fournier described the most important criteria of the disease as sudden onset of painful scrotal edema in healthy young males, rapid progression into the gangrene and absence of an etiologic cause. ${ }^{[2,27]}$ Since then, the epidemiologic properties, clinical features and incidence of FG have changed dramatically. The incidence of the disease has increased toward the end of the 20th century. In the literature, there were 209 reported cases of FG from 1764 through 1950. It was 177 from 195I through 1978, 449 from 1979 through 1988; and II00 from 1989 through 2000. ${ }^{[3,28]}$ Increased incidence of chronic illness as a result of the aging population may be the explanation for the rise of FG now-a-days. ${ }^{[3]}$

FG is not a disease limited to young males as originally thought by Fournier. ${ }^{[26,27]}$ The previous reports suggested the highest incidence of male patients in the 6th decade of life. [29-33] Even with the lower incidence rates, the disease was found in females and in all age groups of childhood including newborn and infancy periods. ${ }^{[33-40]}$

The results of the present report were in agreement with the literature regarding age and sex. The most affected patients were the males aged between 50 and 60 years. There was predominance of male patients over females, with a male:female ratio of 19:1, which was reported between 2.5:1 and 171:0 in the literature. ${ }^{[3,5,40-42]}$ According to Ferreira et al., the incidence of FG is lower in female patients because of better drainage of the genital secretions due to the vaginal tract. ${ }^{[29]}$ But, once the FG is established, the female gender, which is an advantage in terms of disease incidence, becomes a risk factor in terms of mortality. The direct extension of the infection intra-abdominally through the Fallopian tubes may yield to fatal peritonitis and multi-organ failure in female patients. ${ }^{[43]}$ In consistent with this data, abdominal involvement $(75 \%)$ and mortality rate of female patients $(25 \%)$ were higher than males in the present report.

FG is no longer considered idiopathic since the pathologic features of the disease are well-defined and portals of entry for causative microorganisms are well-known. There are reported etiologic causes such as colorectal carcinoma, ${ }^{[4,45]}$ sigmoid carcinoma, ${ }^{[46]}$ perianal/perirectal abscess,,${ }^{[5,29,47,48]}$ ruptured appendicitis, ${ }^{[49,50]}$ sigmoid diverticulitis, ${ }^{\left[{ }^{51]}\right.}$ Bartholin gland abscess, ${ }^{[2,5,6]}$ renal abscess, ${ }^{[52]}$ urethral stone, ${ }^{[53]}$ urethral stricture, ${ }^{[13,54]}$ etc. The most common etiologic cause was perianal abscess (11.25\%) in a total of our cases that followed by chronic perineal irritation (7.5\%) and surgically drainage of perianal abscess $(3.75 \%)$ (Table 3 ).

In the literature, urethral catheterization, ${ }^{[55]}$ vasectomy, ${ }^{[56,57]}$ prostate biopsy, ${ }^{[58]}$ neonatal circumcision, ${ }^{[35,38]}$ hernia re- pair, ${ }^{[59,60]}$ hemorrhoidectomy, ${ }^{[6]]}$ episiotomy, ${ }^{[62-64]}$ and hysterectomy ${ }^{[43]}$ were reported as surgical; anal intercourse, ${ }^{[65]}$ coitus, ${ }^{[26,66]}$ urethral ${ }^{[67,68]}$ or anal foreign body, ${ }^{[69,70]}$ penile selfinjection with cocaine, ${ }^{[7]]}$ heroin injection into the femoral vessels ${ }^{[2]}$ and mechanical erection aid device usage ${ }^{[4]}$ were reported as the non-surgical traumatic causes for FG. The source of the pathogens may be colorectal region, genitourinary tract or cutaneous flora with respect to the mechanism of trauma.

In the present report, traumatic factors were responsible in 20 patients (25\%). Twelve cases developed FG after invasive procedures within 2 months prior to disease onset including drainage of perianal abscess, hemorrhoidectomy, incisional hernia repair, femoral hernia repair, surgery for penetrating intestinal injury, flap closure of sacral pressure sore, balloon dilatation for BPH, and TUR-P. Furthermore, there was a female patient with extended abdomino-perineal involvement of FG in the week following a cesarean section (Table 3). Interestingly, six of the patients that engaged in farming defined chronic perineal trauma due to pricking of thorn while working in the field.

One of our patients was referred to the emergency department with fever, pain, and swelling with gangrenous perineal skin. He had undergone aortobifemoral by-pass grafting for Leriche syndrome five months ago and had a trauma that was caused by falling on to hip in the previous week. After wound debridement, a modified pudendal thigh flap was performed in the treatment of the perineal defect successfully. ${ }^{[72]}$ Leriche syndrome is an aortoiliac occlusive disease with a decreased blood flow to the pelvic region ${ }^{[73,74]}$ in which a successful aortobifemoral by-pass grafting restored the circulation of the lower extremities to an almost normal state. In this case, diminished blood flow to the pelvic region due to by-pass occlusion and inoculation of the cutaneous flora to the deeper tissues as a result of pelvic trauma were considered as the triggering factors for FG. This case was the excellent example for the association of vascular occlusive diseases and trauma in the etiopathogenesis of FG.

In our opinion, as a result of surgical or non-surgical trauma, seeding the causative microorganisms to the subcutaneous tissues due to disruption of skin and mucous membranes' integrity and extension of the infection through the fascial planes is the physiopathological explanation for FG. Additionally, comorbidities that resulted in immunosuppression, tissue ischemia, and oxygenation disturbance increase tendency to the disease. The studies concerning the effect of trauma in the etiopathogenesis of FG date back to the 18th century. In 1764, Baurienne reported a I4-year-old case with FG secondary to being gored by an ox's horn. The patient presented with clinical signs and symptoms directly attributable to FG including pain and gangrenous scrotum. The patient recovered after a prolonged hospital course with secondary intention of the wound following serial debridements. ${ }^{[25,75]}$ 
Identified risk factors for FG are as follows: increased age, ethanol abuse, immunosuppressive conditions such as DM, steroid usage, malignancies etc. ${ }^{[5-16]}$ According to the literature, ${ }^{[6,16]}$ the most frequent pre-existing comorbidity was DM in the present report $(n=34,42.5 \%)$. Controversy still exists as to whether or not DM is associated with poor prognosis in FG. In contrast to previous reports ${ }^{[5,16,76]}$ Steinman et al. ${ }^{[7]]}$ defined DM as a statistically significant factor when associated with bad prognosis. Immunocompromision due to impairment of neutrophil functions ${ }^{[78]}$ and tissue ischemia due to micro- and macro-angiopathies, increase tendency to FG and other infectious diseases in diabetic patients. ${ }^{[12]}$ In addition, 28 of our patients had comorbidities including smoking, CAD, ethanol abuse, Leriche syndrome, and FMF that leaded to vascular occlusive diseases, tissue ischemia and decreased host defense, as well as DM.

FG is a polymicrobial and synergistic infection in which aerobic and less frequently anaerobic microorganisms may be identified. ${ }^{[2]}$ According to the literature, ${ }^{[2,7,44,79,80]} E$. coli was the most frequently identified microorganism $(n=43,53.75 \%)$ in the present report. Due to the rapid progression of necrotizing infection, use of double or triple wide-spectrum antibiotics initially are necessary to bring the infection under control. ${ }^{[48]}$ The most preferred antibiotics according to antibiotic susceptibility results were ciprofloxacin and clindamycin in the present report (Table 5).

Scrotum was the most affected anatomic location that followed by perianal region in this series. As described in the literature ${ }^{[56,81]}$ abdominal wall $(n=5,6.25 \%)$, and thighs $(n=I, 1.25 \%)$ were areas in which the necrotizing infection was observed less frequently. Furthermore, the incidence of the abdominal wall involvement was higher in females when compared with males. The necrotizing process may extend to the abdominal wall due to the continuity of perineal colles' and abdominal Scarpa's fascia. ${ }^{[6]}$ In agreement with the report of Unal et al., ${ }^{[78]}$ mortality rate was higher in patients with abdominal wall involvement (40\%). The explanation may be that involvement of the abdominal wall leads to larger defects that resulted in worst clinical condition, need for more challenging reconstructive techniques, and thus higher morbidity and mortality rate.

The testes are rarely affected in FG due to their separate blood supply ${ }^{[2]}$ and incidence of orchiectomy due to gangrenous testes ranges $10-30 \%$ in the literature. ${ }^{[8,15,21]}$ In six of our cases, testes were evaluated as necrotic that required unilateral orchiectomy. In our serial, preventive colostomy was performed in 12 patients (15\%) who had a sphincteric infection or high-risk of fecal contamination due to large perianal defects. In addition, suprapubic cystostomy was performed in 7 (8.75\%) of our patients due to urethral involvement and urinary extravasation. Despite of reported higher mortality rates in patients in whom colostomy and/or cystostomy were performed, ${ }^{[41,82,83]}$ non-survivors of this series had neither colostomy, nor cystostomy.
The diagnosis of FG is generally based on clinical findings during hospital admission. Radiologic examinations such as ultrasonography, plain radiographs or computed tomography may assist as a diagnostic tool. In the present report, ultrasonography was chosen primarily to support the diagnosis in suspected clinical presentations. Morrison et al. reported the pathognomonic ultrasonographic findings for FG as the thickening of the scrotal skin and subcutaneous gaseous accumulations. ${ }^{[84]}$

Following diagnosis, immediately performed surgical debridement of the necrotic tissues, systemic anti-biotherapy and adequate fluid replacement are of the essence in the treatment of FG.

The main purpose of the surgical debridement is to remove devitalized tissues and to prevent the progression of the necrotizing infection and sepsis. The necrotic tissues should be debrided aggressively until viable tissues were encountered.

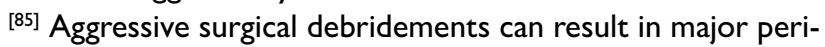
neal, thigh, or abdominal skin loss, which poses a significant challenge to reconstructive surgeons. ${ }^{[86]}$ The timing of surgical debridement in cases of FG is an important factor for the prognosis of the disease. Pre-hospital delay time and ability of the patient to tolerate a surgical procedure are some of the factors that affect the timing of surgical procedure. In the present report, time to initial debridement was $5.76 \pm 4.58$ days for survivors and $6.66 \pm 8$. 14 days for non-survivors that showed statistically no significant difference.

Delayed hospital admission was associated with the higher mortality rate in the previous reports. ${ }^{[5,41,47,81]}$ However, Laor et al. ${ }^{[87]}$ and Moorthy et al. ${ }^{[88]}$ affirmed that there is presently no strong evidence for either acute or delayed hospital admission with the prognosis of the disease. The pre-hospital delay time was not significantly different between survivors (5.45 \pm 4.50 days) and non-survivors ( $6 \pm 5.7$ days) in the present report.

Reported mortality rates of FG are ranged between $9 \%$ and $43 \%$ in the literature. ${ }^{[14,17-24]}$ Lower mortality rate of the present report $(3.75 \%)$ may be explained by the unconsulted patients from other departments due to rapid fatal course.

Cutaneous defects due to FG require challenging aesthetic and functional reconstruction. Skin grafts, muscle flaps, musculocutaneous flaps, and fascia-cutaneous flaps ${ }^{[89,90]}$ have been used for this purpose, but a satisfactory functional and esthetic outcome is rarely achieved. The extent and the location of the cutaneous defect are the crucial factors in the selection of the most appropriate treatment option. ${ }^{\text {91] }}$

In the present report, variable reconstructive techniques were performed in order to close the cutaneous defects. Primary closure $(n=27,33.75 \%)$ was the most common technique used for all patients, followed by the skin grafting, 
scrotal flap, pudendal thigh flap, super-thin groin island flap, gracilis musculocutaneous flap, abdominal advancement flap, and groin flap, respectively (Table 6). It has been suggested that using skin grafts to reconstruct larger defects will reduce the hospitalization time and provide a thinner covering. ${ }^{\left[{ }^{89]}\right.}$ In addition, the texture of external genitalia that provided by skin graft are usually far from being natural due to the possibility of scar contracture and synechiae. In our opinion, skin grafting is useful due to its simplicity and reliability and helpful in thermoregulation of the testes. Forming scrotal neo-septum by suturing the sides of the testes facing each other and covering them with a skin graft provide more natural-looking results in cases with bilaterally exposed testes (Fig. 4).

Scrotal flap is useful for repairing small to medium-sized defects of the scrotum and provide a perfect cover for the exposed testes in terms of aesthetics and functionality. Thin and unstretched coverage is obtained by dissecting the scrotal skin laterally. In cases with inadequate scrotal flap dimension, testes were buried in thigh pockets for facilitating the closure of the wound. Salvage of the testes by burial is associated with detrimental psychological effects and has been shown to have a negative impact on spermatogenesis. ${ }^{\text {[2] }}$

Bilaterally expanded super-thin groin island flap is an alterna- tive technique in the closure of extensive perineal defects and maintains almost a suitable, thin cover. Large defects can be closed by this technique without achieving a bulky flap formation in the scrotal and penile region. On the other hand, it provides significant benefit in thermoregulation of the testes. The disadvantage of this flap is that it requires tissue expansion and two operative sessions for closure of the defect. [91] We performed this flap in two of our patients without any complications. The gracilis musculocutaneous flap was performed in two of our patients with large defects of the perineal region. The main disadvantage of the gracilis musculocutaneous flap is the bulky nature of the flap and the necessity to use a functional muscle. ${ }^{[93]}$

Pudendal thigh flap is satisfactory functionally and cosmetically. Some of its advantages are that (a) ability to easy application, (b) resulting in an inconspicuous linear scar in the donor site, and (c) having a reliable blood supply. ${ }^{[94]}$ We used pudendal thigh flap in seven of our patients in this series. We only experienced minimal necrosis in the distal end of the flap in one patient, minimal wound dehiscence in two patients that healed by conservative means.

\section{Conclusion}

FG still has a high mortality rate despite aggressive surgical
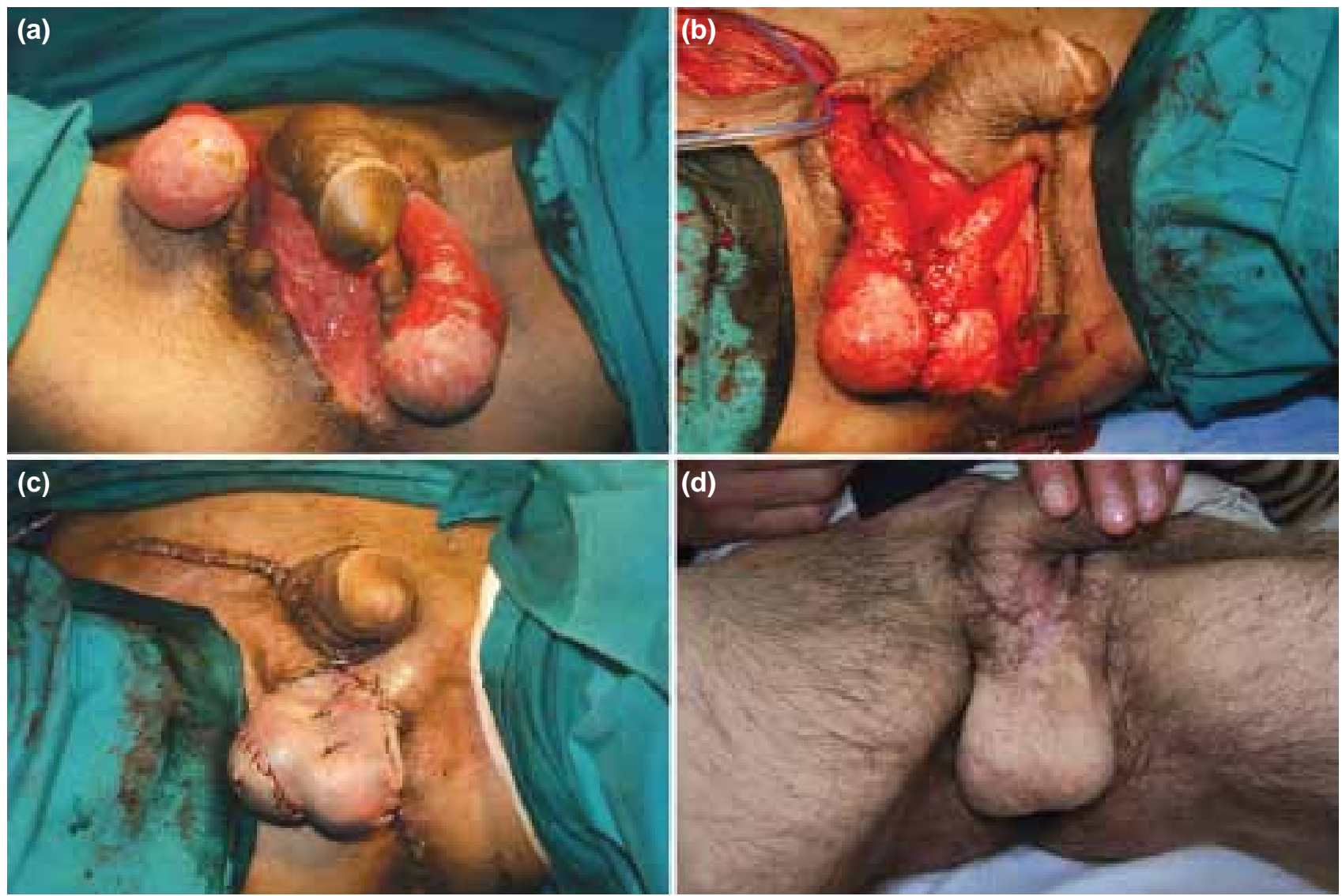

Figure 4. A patient with a scrotal split-thickness graft. (a) Pre-operative view of testes and scrotum. (b) Intra-operative view of testes that sutured together in order to form the scrotal neo-septum. (c) Intra-operative view of testes after covering with split-thickness skin graft. (d) One year post-operative view of scrotum. 
debridements, modern antimicrobial drugs and intensive care units. Rapid and correct diagnosis of FG can avoid inappropriate or delayed treatment and even death of the patient. The healthcare professionals should be aware that any trauma in the perineal region could lead to FG.

\section{Conflict of interest: None declared.}

\section{REFERENCES}

1. Vick R, Carson CC 3rd. Fournier's disease. Urol Clin North Am 1999;26:841-9. CrossRef

2. Laucks SS 2nd. Fournier's gangrene. Surg Clin North Am 1994;74:133952.

3. Eke N. Fournier's gangrene: a review of 1726 cases. Br J Surg 2000;87:718-28. CrossRef

4. Theiss M, Hofmockel G, Frohmüller HG. Fournier's gangrene in a patient with erectile dysfunction following use of a mechanical erection aid device. J Urol 1995;153:1921-2. CrossRef

5. Yanar H, Taviloglu K, Ertekin C, Guloglu R, Zorba U, Cabioglu N, et al. Fournier's gangrene: risk factors and strategies for management. World J Surg 2006;30:1750-4. CrossRef

6. Yaghan RJ, Al-Jaberi TM, Bani-Hani I. Fournier's gangrene: changing face of the disease. Dis Colon Rectum 2000;43:1300-8. CrossRef

7. Jeong HJ, Park SC, Seo IY, Rim JS. Prognostic factors in Fournier gangrene. Int J Urol 2005;12:1041-4. CrossRef

8. Hejase MJ, Simonin JE, Bihrle R, Coogan CL. Genital Fournier's gangrene: experience with 38 patients. Urology 1996;47:734-9. CrossRef

9. Hollabaugh RS Jr, Dmochowski RR, Hickerson WL, Cox CE. Fournier's gangrene: therapeutic impact of hyperbaric oxygen. Plast Reconstr Surg 1998;101:94-100. CrossRef

10. Elem B, Ranjan P. Impact of immunodeficiency virus (HIV) on Fournier's gangrene: observations in Zambia. Ann R Coll Surg Engl 1995;77:283-6.

11. Stephens BJ, Lathrop JC, Rice WT, Gruenberg JC. Fournier's gangrene: historic (1764-1978) versus contemporary (1979-1988) differences in etiology and clinical importance. Am Surg 1993;59:149-54.

12. Baskin LS, Carroll PR, Cattolica EV, McAninch JW. Necrotising soft tissue infections of the perineum and genitalia. Bacteriology, treatment and risk assessment. Br J Urol 1990;65:524-9. CrossRef

13. Clayton MD, Fowler JE Jr, Sharifi R, Pearl RK. Causes, presentation and survival of fifty-seven patients with necrotizing fasciitis of the male genitalia. Surg Gynecol Obstet 1990;170:49-55.

14. Aşci R, Sarikaya S, Büyükalpelli R, Yilmaz AF, Yildiz S. Fournier's gangrene: risk assessment and enzymatic debridement with lyophilized collagenase application. Eur Urol 1998;34:411-8. CrossRef

15. Wolach MD, MacDermott JP, Stone AR, deVere White RW. Treatment and complications of Fournier's gangrene. Br J Urol 1989;64:310-4. CrossRef

16. Torremadé Barreda J, Millán Scheiding M, Suárez Fernández C, Cuadrado Campaña JM, Rodríguez Aguilera J, Franco Miranda E, et al. Fournier gangrene. A retrospective study of 41 cases. [Article in Spanish] Cir Esp 2010;87:218-23. [Abstract] CrossRef

17. Kouadio K, Kouame YJ, Bi KL, Turquin HH. Perineal gangrene: report of 30 cases observed at Abidjan. [Article in French] Med Trop (Mars) 1998;58:245-8. [Abstract]

18. Fahal AH, Hassan MA. Fournier's gangrene in Khartoum. Br J Urol 1988;61:451-4. CrossRef

19. Brissiaud JC, Azam P, Paret B, Lopy J, Louis C, Collet F. Skin gangrene of the external genitalia. Report of 44 cases. [Article in French] Chirurgie
1998;123:387-93. [Abstract] CrossRef

20. Benchekroun A, Lachkar A, Bjijou Y, Soumana A, Faik M, Marzouk M, et al. Gangrene of the external genital organs. Apropos of 55 cases. [Article in French] J Urol (Paris). 1997;103:27-31. [Abstract]

21. Picramenos D, Deliveliotis C, Macrichoritis K, Alexopoulou K, Kostakopoulos A, Dimopoulos C. [Fournier's gangrene: etiology, treatment, and complications]. [Article in French] Prog Urol 1995;5:701-5. [Abstract]

22. Somers WJ, Lowe FC. Localized gangrene of the scrotum and penis: a complication of heroin injection into the femoral vessels. J Urol 1986;136:111-3.

23. Palmer LS, Winter HI, Tolia BM, Reid RE, Laor E. The limited impact of involved surface area and surgical débridement on survival in Fournier's gangrene. Br J Urol 1995;76:208-12. CrossRef

24. el Khader K, el Fassi J, Nouri M, Ibn Attya A, Hachimi M, Lakrissa A. Fournier's gangrene. Analysis of 32 cases. J Urol (Paris). 1997;103:32-4.

25. Baurienne H. Sur uneplaie contuse qui s'esttermine' e par le sphacèle de le scrotum. J Med Chir Pharm 1764;20:251-6.

26. Fournier JA. Gangrene foudroyante de la verge. Semaine Med 1883;3:345.

27. Fournier JA. Etude clinique de la gangrene foudroyante de la verge. Semaine Med 1884;4:69.

28. Yalamarthi S, Dayal S. Fournier's gangrene: lectures and tutorials. The Royal College of Surgeons of Edinburgh Surgical Knowledge and Skill Web site. http://www.edu.rcsed.ac.uk/lectures/lt33.htm. Accessed June 1, 2008.

29. Ferreira PC, Reis JC, Amarante JM, Silva AC, Pinho CJ, Oliveira IC, et al. Fournier's gangrene: a review of 43 reconstructive cases. Plast Reconstr Surg 2007;119:175-84. CrossRef

30. Tahmaz L, Erdemir F, Kibar Y, Cosar A, Yalcýn O. Fournier's gangrene: report of thirty-three cases and a review of the literature. Int J Urol 2006;13:960-7. CrossRef

31. Mindrup SR, Kealey GP, Fallon B. Hyperbaric oxygen for the treatment of fournier's gangrene. J Urol 2005;173:1975-7. CrossRef

32. Başoğlu M, Gül O, Yildirgan I, Balik AA, Ozbey I, Oren D. Fournier's gangrene: review of fifteen cases. Am Surg 1997;63:1019-21.

33. Rodríguez Alonso A, Pérez García MD, Núnez López A, Ojea Calvo A, Alonso Rodrigo A, Rodríguez Iglesias B, et al. Fournier's gangrene: anatomo-clinical features in adults and children. Therapy update. [Article in Spanish] Actas Urol Esp 2000;24:294-306. [Abstract] CrossRef

34. Güneren E, Keskin M, Uysal OA, Aritürk E, Kalayci AG. Fournier's gangrene as a complication of varicella in a 15-month-old boy.J Pediatr Surg 2002;37:1632-3. CrossRef

35. Sussman SJ, Schiller RP, Shashikumar VL. Fournier's syndrome. Report of three cases and review of the literature. Am J Dis Child 1978;132:118991. CrossRef

36. Adams JR Jr, Mata JA, Venable DD, Culkin DJ, Bocchini JA Jr. Fournier's gangrene in children. Urology 1990;35:439-41. CrossRef

37. Ekingen G, Isken T, Agir H, Oncel S, Günlemez A. Fournier's gangrene in childhood: a report of 3 infant patients. J Pediatr Surg 2008;43:e3942. CrossRef

38. Woodside JR. Necrotizing fasciitis after neonatal circumcision. Am J Dis Child 1980;134:301-2.

39. Adeyokunnu AA. Fournier's syndrome in infants. A review of cases from Ibadan, Nigeria. Clin Pediatr (Phila) 1983;22:101-3. CrossRef

40. Ayumba BR, Magoha GA. Epidemiological aspects of Fournier's gangrene at Kenyatta National Hospital, Nairobi. East Afr Med J 1998;75:586-9.

41. Korkut M, Içöz G, Dayangaç M, Akgün E, Yeniay L, Erdoğan O, et al. Outcome analysis in patients with Fournier's gangrene: report of 45 cases. Dis Colon Rectum 2003;46:649-52. CrossRef 
42. Chen SY, Fu JP, Wang CH, Lee TP, Chen SG. Fournier gangrene: a review of 41 patients and strategies for reconstruction. Ann Plast Surg 2010;64:765-9. CrossRef

43. Czymek R, Frank P, Limmer S, Schmidt A, Jungbluth T, Roblick U, et al. Fournier's gangrene: is the female gender a risk factor? Langenbecks Arch Surg 2010;395:173-80. CrossRef

44. Gamagami RA, Mostafavi M, Gamagami A, Lazorthes F. Fournier's gangrene: an unusual presentation for rectal carcinoma. Am J Gastroenterol 1998;93:657-8. CrossRef

45. Eke N. Colorectal cancer presenting as Fournier's gangrene. Am J Gastroenterol 1999;94:858-9. CrossRef

46. Dewire DM, Bergstein JM. Carcinoma of the sigmoid colon: an unusual cause of Fournier's gangrene. J Urol 1992;147:711-2.

47. Kiliç A, Aksoy Y, Kiliç L. Fournier's gangrene: etiology, treatment, and complications. Ann Plast Surg 2001;47:523-7. CrossRef

48. Czymek R, Hildebrand P, Kleemann M, Roblick U, Hoffmann M, Jungbluth T, et al. New insights into the epidemiology and etiology of Fournier's gangrene: a review of 33 patients. Infection 2009;37:306-12. CrossRef

49. Gerber GS, Guss SP, Pielet RW. Fournier's gangrene secondary to intraabdominal processes. Urology 1994;44:779-82. CrossRef

50. Gaeta M, Volta S, Minutoli A, Bartiromo G, Pandolfo I. Fournier gangrene caused by a perforated retroperitoneal appendix: CT demonstration. AJR Am J Roentgenol 1991;156:341-2. CrossRef

51. Klutke CG, Miles BJ, Obeid F. Unusual presentation of sigmoid diverticulitis as an acute scrotum. J Urol 1988;139:380-1.

52. Fialkov JM, Watkins K, Fallon B, Kealey GP. Fournier's gangrene with an unusual urologic etiology. Urology 1998;52:324-7. CrossRef

53. Campos JA, Martos JA, Gutiérrez del Pozo R, Carretero P. Synchronous caverno-spongious thrombosis and Fournier's gangrene. Arch Esp Urol 1990;43:423-6.

54. McGeehan DF, Asmal AB, Angorn IB. Fournier's gangrene. S Afr Med J 1984;66(:734-7.

55. Conn IG, Lewi HJ. Fournier's gangrene of the scrotum following traumatic urethral catheterisation. J R Coll Surg Edinb 1987;32:182-4.

56. Viddeleer AC, Lycklama à Nijeholt GA. Lethal Fournier's gangrene following vasectomy. J Urol 1992;147:1613-4.

57. Patel A, Ramsay JW, Whitfield HN. Fournier's gangrene of the scrotum following day case vasectomy. J R Soc Med 1991;84:49-50.

58. Vástyán A, Gulácsy I, Fazekas Z. Fournier gangrene following prostatic puncture. [Article in Hungarian] Orv Hetil 1994;135:2039-40. [Abstract]

59. Lamb RC, Juler GL. Fournier's gangrene of the scrotum. A poorly defined syndrome or a misnomer? Arch Surg 1983;118:38-40. CrossRef

60. Moustafa MF. Gangrene of the scrotum: an analysis of ten cases. Br J Plast Surg 1967;20:90-6. CrossRef

61. Bönner C, Prohm P, Störkel S. Fournier gangrene as a rare complication after stapler hemorrhoidectomy. Case report and review of the literature. [Article in German] Chirurg 2001;72:1464-6. [Abstract] CrossRef

62. Häusler G, Hanzal E, Dadak C, Gruber W. Necrotizing fasciitis arising from episiotomy. Arch Gynecol Obstet 1994;255:153-5. CrossRef

63. Lynch CM, Pinelli DM, Cruse CW, Spellacy WN, Sinnott JT, Shashy RG. Maternal death from postpartum necrotizing fasciitis arising in an episiotomy: a case report. Infect Dis Obstet Gynecol 1997;5:341-4. CrossRef

64. Sutton GP, Smirz LR, Clark DH, Bennett JE. Group B streptococcal necrotizing fasciitis arising from an episiotomy. Obstet Gynecol 1985;66:733-6.

65. Bernstein SM, Celano T, Sibulkin D. Fournier's gangrene of the penis. South Med J 1976;69:1242-4. CrossRef
66. Waldbaum RS, Bordan DL, Wise AJ. Use of procine zenografts in treatment of Fournier's gangrene. Urology 1975;05:374-6. CrossRef

67. Berveiller P, Tariel E, Benayoun M, Bourgeois E, Desgrandchamps F. Fatal intraurethral foreign body. Presse Med 2010;39:408-9. CrossRef

68. Jalón Monzón A, García Rodríguez J, Sánchez Trilla A, Rodríguez Martínez JJ, Rodríguez Faba O, Fernández Gómez JM, et al. A chicken bone as cause of Fournier gangrene. [Article in Spanish] Arch Esp Urol 2003;56:1147-50. [Abstract]

69. Gutiérrez-Cabello F, Sevilla Feijoo P, Hawari Meilud A, Jiménez-Alonso J. Fournier's gangrene with fatal progress by a fish bone. [Article in Spanish] Med Clin (Barc) 2006;126:99. [Abstract]

70. Moreira CA, Wongpakdee S, Gennaro AR. A foreign body (chicken bone) in the rectum causing extensive perirectal and scrotal abscess: report of a case. Dis Colon Rectum 1975;18:407-9. CrossRef

71. Mouraviev VB, Pautler SE, Hayman WP. Fournier's gangrene following penile self-injection with cocaine. Scand J Urol Nephrol 2002;36:317-8.

72. Coruh A, Akcali Y, Ozcan N, Ekmekcioglu O. Modified pudendal thigh flap for perineoscrotal reconstruction: a case of Leriche syndrome with rapidly progressing Fournier's gangrene. Urology 2004;64:1030. CrossRef

73. Elsharawy MA, Cheatle TR. Buttock claudication secondary to isolated internal iliac artery stenosis. Eur J Vasc Endovasc Surg 2000;19:87-9.

74. Duff C, Simmen HP, Brunner U, Bauer E, Turina M. Gluteal necrosis after acute ischemia of the internal iliac arteries. Vasa 1990;19:252-6.

75. Medina PJ, González-Rivas FA, Blanco AM, Tejido SA, Leiva GO. Historical review of Fournier's gangrene: Baurienne, 1764 and Herod the Great, 4 B.C. European Urology Supplements 2009;8:121. CrossRef

76. Nisbet AA, Thompson IM. Impact of diabetes mellitus on the presentation and outcomes of Fournier's gangrene. Urology 2002;60:775-9. CrossRef

77. Steinman E, Utiyama EM, Maximiniano LF, Belivacqua RG, Birolini D. Fournier syndrome: evaluation and initial treatment. [Article in Portuguese] Rev Assoc Med Bras 1992;38:209-13. [Abstract]

78. Unal B, Kocer B, Ozel E, Bozkurt B, Yildirim O, Altun B, et al. Fournier gangrene. Approaches to diagnosis and treatment. Saudi Med J 2006;27:1038-43.

79. Basoglu M, Ozbey I, Atamanalp SS, Yildirgan MI, Aydinli B, Polat O, et al. Management of Fournier's gangrene: review of 45 cases. Surg Today 2007;37:558-63. CrossRef

80. Uluğ M, Gedik E, Girgin S, Celen MK, Ayaz C. The evaluation of microbiology and Fournier's gangrene severity index in 27 patients. Int $\mathrm{J}$ Infect Dis 2009;13:e424-30. CrossRef

81. Benizri E, Fabiani P, Migliori G, Chevallier D, Peyrottes A, Raucoules M, et al. Gangrene of the perineum. Urology 1996;47:935-9. CrossRef

82. Yeniyol CO, Suelozgen T, Arslan M, Ayder AR. Fournier's gangrene: experience with 25 patients and use of Fournier's gangrene severity index score. Urology 2004;64:218-22. CrossRef

83. Villanueva-Sáenz E, Martínez Hernández-Magro P, Valdés Ovalle M, Montes Vega J, Alvarez-Tostado F JF. Experience in management of Fournier's gangrene. Tech Coloproctol 2002;6:5-13. CrossRef

84. Morrison D, Blaivas M, Lyon M. Emergency diagnosis of Fournier's gangrene with bedside ultrasound. Am J Emerg Med 2005;23:544-7. CrossRef

85. Scott SD, Dawes RF, Tate JJ, Royle GT, Karran SJ. The practical management of Fournier's gangrene. Ann R Coll Surg Engl 1988;70:16-20.

86. Hesselfeldt-Nielsen J, Bang-Jensen E, Riegels-Nielsen P. Scrotal reconstruction after Fournier's gangrene. Ann Plast Surg 1986;17:310-6. CrossRef

87. Laor E, Palmer LS, Tolia BM, Reid RE, Winter HI. Outcome prediction in patients with Fournier's gangrene. J Urol 1995;154:89-92. CrossRef

88. Moorthy K, Rao PP, Supe AN. Necrotising perineal infection: a fatal outcome of ischiorectal fossa abscesses. J R Coll Surg Edinb 2000;45:281-4. 
89. Maguiña P, Palmieri TL, Greenhalgh DG. Split thickness skin grafting for recreation of the scrotum following Fournier's gangrene. Burns 2003;29:857-62. CrossRef

90. Horton CE, Stecker JF, Jordan GH. Genital reconstruction following trauma. In: McCarthy JG, editor. Plastic surgery. New York: W.B. Saunders; 1990. p. 4226-39.

91. Dogan F, Eskitascioglu T, Altiparmak M, Özyazgan İ. Bilateral super thin groin island flap for penile, scrotal and pubic reconstruction after
Fournier's gangrene. Eur J Plast Surg 2010;34:497-9. CrossRef

92. Datubo-Brown DD. Alternative techniques for scrotal reconstruction. $\mathrm{Br}$ J Urol 1990;65:115-7. CrossRef

93. Kayikçioğlu A. A new technique in scrotal reconstruction: short gracilis flap. Urology 2003;61:1254-6. CrossRef

94. Monstrey S, Blondeel P, Van Landuyt K, Verpaele A, Tonnard P, Matton $\mathrm{G}$. The versatility of the pudendal thigh fasciocutaneous flap used as an island flap. Plast Reconstr Surg 2001;107:719-25. CrossRef

\section{KLINIIK ÇALIŞMA - ÖZET}

\section{Fournier gangreninde 80 hastalık tecrübemiz ve bir etiyopatogenez nedeni olarak "travma" \\ Dr. Teoman Eskitaşcıoğlu, Dr. İrfan Özyazgan, Dr. Atilla Coruh, Dr. Galip K Günay, Dr. Mehmet Altıparmak, Dr. Yalcin Yontar, Fatih Doğan ${ }^{\dagger}$}

Erciyes Üniversitesi Tıp Fakültesi, Plastik Rekonstrüktif ve Estetik Cerrahi Anabilim Dalı, Kayseri

†Şimdiki kurumu: Adıyaman Üniversitesi Tıp Fakültesi, Plastik Rekonstrüktif ve Estetik Cerrahi Anabilim Dalı, Adıyaman

AMAÇ: Bu çalışmanın amacı Fournier gangrenli hastaların bilgilerini geriye dönük olarak analiz etmek ve bunları literatürle karşılaştırarak travmanın bir etiyopatogenez faktörü olarak rolünü araştırmaktır.

GEREÇ VE YÖNTEM: Bölümüzde konsülte edilen 126 Fournier gangrenli hastaların bilgileri geriye dönük olarak analiz edildi.

BULGULAR: Fournier gangrenli 80 hastanın 76'sı erkek, dördü kadın idi. Hastaların ortalama yaşları $53.5 \pm$ I 3.6 idi. Hastalardaki en sık başvuru nedeni şişlik idi $(n=74)$. Hastalardaki en sık etkilenen bölge skrotum idi $(n=75)$. Fournier gangreni için diabetes mellitus predispozan faktör iken travma Fournier gangreni oluşumundan sorumlu olan faktördü. Escherichia coli en sık izole edilen mikroorganizmaydı ( $n=43$, \%53.75). Primer kapatım en sık uygulanan teknikdi. Sepsis ve çoklu organ yetersizliği nedeni ile üç hasta hayatın kaybetti.

TARTIŞMA: Fournier gangreni halen yüksek mortaliteye sahiptir. Hastalığın hızlı ve doğru teşhisi uygunsuz ve geç tedaviyi ve de hasta mortalitesini önler. Sağlık çalışanlarının perineal bölge travması olan hastalarda Fournier gangreni gelişebileceği hususunda uyanık olmaları gereklidir.

Anahtar sözcükler: Fournier gangreni; rekonstrüksiyon; travma.

Ulus Travma Acil Cerrahi Derg 20।4;20(4):265-274 doi: 10.5505/tjtes.20।4.67670 